\title{
Maaseutu isossa kuvassa
}

DOI: $10.51807 /$ maaseutututkimus. 112884

$\mathrm{H}$

yvinvointia, taloutta ja tulevaisuutta selitetään nykyisin sujuvasti kaupunkien kautta: kaupungistuminen esitetään kaiken kattavana, kaikkialle ulottuvana ja kaikkea kuvaavana. Nähdäksemme kyse on kuitenkin harhasta - kuvasta puuttuu maaseutu. Maaseutu jää alisteiseksi, jos annamme kritiikittä vajaan kokonaisuuden esittää täydellistä. Tämän julkaisun tarkoituksena on tuoda maaseudut takaisin kuvaan ja osaksi kestävyysmuutosta koskevaa keskustelua.

Maaseudun ja kaupungin suhde ei ole koskaan ollut staattinen, vaan ajassa elävä. Suhde ilmenee monilla tavoilla ja siinä on sekä pysyviä että eritahtisesti muuttuvia muotoja. Adjektiivilla elävä haluamme korostaa maaseudun ja kaupungin vuorovaikutuksen dynaamista luonnetta. Vuorovaikutuksella on iso merkitys molempien osapuolten elinvoiman, mutta myös yhteiskunnan kestävän kehityksen kannalta.

Kaupungin ja maaseudun käsitteiden välistä suhdetta voi lähestyä käsitteellisenä metonymiana. Boaventura de Sousa Santosin (2016) mukaan metonymista rajoittuneisuutta on toiminnan tarkastelu suhteessa kokonaisuuteen niin, että kokonaisuudella on yliote osista, jotka sen muodostavat. Metonymian vallitessa osat eivät voi olla itsenäisesti edes olemassa.

Kaupunki ja maaseutu nähdään usein vastakohtina. Juuri dikotomioissa kokonaisuuden ylivalta on usein täydellisimmillään, sillä dikotomiat nähdään yleensä sekä symmetrisinä että hierarkkisina. Symmetria on horisontaalinen suhde, jonka taakse hierarkia pääsee piiloutumaan. De Sousa Santosin mukaan metonymistä käsitteistöä käytetään kuvaamaan erilaisista osista muodostuva osa-kokonaisuus osiensa täydellisenä summana, eli koko kokonaisuutena. Jos tämän "vajaan” kokonaisuuden annetaan kritiikittä ja erheellisesti esittää "täydellistä", sen osat kuvataan toistuvasti alisteisina. 
Yksi keino vapautua haitallisista dikotomioista on esittää vaihtoehtoisia suhteutuksia: käsitteellistää esimerkiksi periferia tavalla, jossa ei ole ydintä, tai puhua maaseudusta ilman pakollista puhetta vaikkapa maataloudesta. De Sousa Santosin ajatus on, että dikotomian syntyessä sen ulkopuolelle on jäänyt fragmentteja tai suurempiakin osia kokonaisuudesta pyörimään käsiteavaruuden välitilassa kuin meteoriitit. Tämä metonymisten dikotomioiden ulkopuolelle jäänyt aines saattaa sisältää paljon mielenkiintoista. Marginaaleihin on saattanut ajautua dikotomian vallan sivuuttamia asioita ja ihmiskohtaloita, jopa yhteiskunnallista edistystä. (Schmidt-Thomé \& Vihinen 2006.)

Kaupungistuminen on keskeinen osa modernisaatiota koskevaa keskustelua. Monine yhteiskunnallisine vaikutuksineen 1800-lukua voidaan pitää aikakautena, joka herätti poikkeuksellisen voimakasta keskustelua kehityksen suunnasta ja tavoitteista. Yleistäen voidaan sanoa, että tuo aikakausi rakensi kaupungistumisesta ihmisten toiveiden täyttymyksen. Kaupungistuminen on koettu edistyksenä siitä huolimatta, että kaupunkien kasvu on ollut myös hyvin ristiriitainen ja voimakkaita jännitteitä synnyttänyt kehitys.

Kaupungistuva kulttuurimme ei ole niinkään pyrkinyt sopeutumaan luonnon asettamiin ehtoihin vaan pikemminkin ylittämään ne luovuutta ja teknologiaa hyödyntäen. Taustalla on ollut usko ihmisen kykyyn asettaa tavoitteet itsenäisesti, tahtonsa ja valtansa mukaan. Tämä edistyksen nimissä luotu kulttuuri nähtiin pitkään luonnosta erillisenä, jopa vastakkaisena kokonaisuutena. Nykyisin jyrkkä kulttuurin ja luonnon välinen erottelu ei ole kestävä tapa ajatella. Se on haastettu erityisesti biosfäärin reunaehtojen tiedostamisen myötä: edistystä ei voi olla kehitys, joka aiheuttaa luonnon kestokyvyn kanssa ristiriidassa olevia muutoksia. Kasvun rajojen lähestyessä on paikallaan korostaa kulttuurin ja luonnon vastavuoroisuuden ja tasapainon merkitystä.

Emme ole tottuneet ajatukseen, että myös maaseudun kehittyminen (maaseutuistuminen) voitaisiin laajemmin tulkita yhteiskunnallisena edistyksenä. Ajatuksen hyväksyminen on vaikeata, jos maaseudun kehitys nähdään olevan ristiriidassa kaupungistumiseen liittyvien, tavoiteltaviksi koettujen vaikutusten ja hyötyjen kanssa. Kaupungit kiinnostavat ja kiehtovat, sillä useat sukupolvet ovat eläneet todeksi kaupunkien nousun ja kukoistuksen. Ajatus kaupungistumisen läpitunkevasta vaikutuksesta nykypäivän yhteiskuntiin on vahva. 
Kaupungistuminen ei kuitenkaan ole koskaan edennyt suoraviivaisesti. Se on ollut aaltoliikettä ja syklistä muutosta. Toisina aikakausina tietyn kokoiset kaupungit kasvavat ja vetävät puoleensa ihmisiä tarjoamalla mahdollisuudet parempaan toimeentuloon tai elämänlaatuun. Kasvu on nopeaa johonkin rajaan asti, mutta hidastuu keskusten keskinäisten suhteiden muututtua riittävästi. (Geyer \& Kontuly 1993.)

Kaupunkien kasvun taittumista on selitetty myös kaupungistumisen negatiivisilla sivuvaikutuksilla: liikenteen ruuhkautuminen, asumisen hintojen nousu, ilman ja veden saastuminen ovat pois ihmisten elämänlaadusta ja talouden tuottavuudesta. Keskipakoinen kehitys käynnistyy, jos laatu ei kulje määrän tahdissa, ja ihmiset karttavat näitä negatiivisia ulkoisvaikutuksia. Jos taas esimerkiksi kaupunkisuunnittelulla ja investoinnilla julkiseen infrastruktuuriin voidaan kiriä laadussa, näiden ratkaisujen kautta voidaan saada käyntiin taas uusi kaupungistumisen vaihe (Laakso \& Loikkanen 2018).

Michael Batty (2018) lähestyy kaupungistumista kompleksisina ja sopeutuvina systeemeinä, jotka käyvät läpi muutosta teollisesta urbaaniin vaiheeseen. Hän arvuuttelee, miten pitkälle kaupungistuminen voi lopulta edetä. Mitä sataprosenttinen kaupungistumisaste edes tarkoittaisi? Veisikö se pohjan koko dikotomialta antaen tilaa muille tavoille eritellä näitä tilallisia suhteita? Battyn mallissa "ei-kaupunki" voisi lopulta olla myös joku muukin kuin maaseutu.

Voimme toki kuvitella vuosikymmenten päähän tilanteen, jossa nykyisiä maaseutuun liittyviksi miellettyjä toimintoja ja maisemia ei enää olisi. Kiinnittyisikö maaseudun käsite niiden tilalle tulleisiin entiteetteihin? Voisivatko esimerkiksi jättimäiset ruoantuotantohallit - teolliset sisätilat - edustaa uutta maaseutua? Entä jos nykyisin maaseutumaisina koetut maisemat luettaisiinkin läpikaupungistuneessa kudoksessa joksikin muuksi, ja kaupunkirakenteen keskelle jääneet "maaseudut" näyttäisivät lähinnä maisemamuseoilta.

Toisaalta maaseutu ei lakkaa olemasta niin kauan kuin puhumme alueista ja paikoista maaseudun käsiteellä ja kuvaamme niitä maaseutuina. Tulevaisuuden maaseutunäkymän voi esittää myös tulevaisuuden mahdollisuutena, kuten Jason Bradford, joka hahmottelee teoksessaan The Future is Rural (2019) käännettä (reruralization), joka tulee tapahtumaan energiamuutoksen, mutta erityisesti ruokaketjun kestävyysvaatimusten kautta. 
Kysymys maaseudun ja kaupungin vuorovaikutuksesta onkin yhteydessä laajempaan kokonaisuuteen ja kysymykseen: miten nykyinen kasvuorientoitunut taloutemme saadaan sopeutettua planeettarajoihin? Tässä prosessissa joudutaan pohtimaan kaikkia yhteiskunnan perustoimintoja ja niiden organisoimista uudesta näkökulmasta. Meidän on kyettävä vähintään sopeuttamaan kulutuksemme luonnonvarojen uusiutumisen rajoihin. Tällä sopeutumisella on myös tilallinen ulottuvuutensa, eli se tulee näkymään myös siinä, miten yhteiskunnat organisoituvat alueellisesti.

Tätä muutoksen suuntaa määritellään julkisissa keskusteluissa, joissa myös maaseudun ja kaupungin suhdetta koskevat tulkinnat pitkälti tuotetaan ja merkityksellistetään. Käsillä oleva julkaisumme on osa tätä keskustelua. Julkaisu koostuu johdantoluvusta, neljästä vertaisarvioidusta osatutkimuksesta sekä tulevaan suuntautuvasta ja jatkokeskustelua virittävästä loppuluvusta. Artikkeleissa nostetaan esiin erilaisia toimijoita ja toimijarooleja, jotka ylläpitävät maaseudun ja kaupungin vuorovaikutusta. ${ }^{1}$

Artikkeleita yhdistää Kansalliskirjaston tutkimuksellinen "aarreaitta", eli digi.kansalliskirjasto.fi -palvelun kautta tutkimuskäyttöön saatu digitaalinen sanoma- ja aikakauslehtiaineisto. Kiitos Kansalliskirjaston ja Kopioston välisen sopimuksen tuo aineisto avautui laajasti tämän julkaisun tutkijoiden käyttöön vuonna 2018.

Haluamme kiittää kaikkia kirjoittajia sekä toimitussihteeri Petja Kauppia osallistumisesta tämän julkaisun tekemiseen. Kiitos myös taiteilija Jasmina Ijäkselle, joka luovutti kansikuvaa varten valokuvan teoksestaan Dikotomia 5 (2018). Lisäksi on lausuttava lämmin kiitos Keskitien säätiölle, joka vuosina 2017-2019 rahoitti merkittävällä osuudella artikkeleiden kirjoittamista Helsingin yliopiston Ruralia-instituutissa toteutetun Maaseudun ja kaupungin suhde (MAKSU) hankkeen kautta.

Koronapandemian ajassa joulukuussa 2021

Torsti Hyyryläinen \& Kaisa Schmidt-Thomé

1 Yhden osatutkimuksen (Kanner \& Hyyryläinen) arviointiprosessin vastuupäätoimittajana on toiminut yksin Kaisa Schmidt-Thomé. 


\section{Kirjallisuus}

Batty, Michael 2018. Inventing Future Cities. MIT press.

Bradford, Jason 2019. The future is rural. Food system adaptations to the great simplification. Post Carbon Institute.

Geyer, Hermanus S. \& Thomas Kontuly 1993. A Theoretical Foundation for the Concept of Differential Urbanization. International Regional Science Review 15, 157-177.

Laakso, Seppo \& Heikki A. Loikkanen 2018. Kaupungistuminen - viimeaikainen ilmiö vai pitkään jatkunut kehityskulku? Kvartti verkkolehti 11.5.2018. Saatavilla: https://www. kvartti.fi/fi/artikkelit/kaupungistuminen-viimeaikainen-ilmio-vai-pitkaanjatkunutkehityskulku. [käytetty 2.9.2021].

de Sousa Santos, Boaventura 2016. A critique of the Lazy Reason: Against the Waste of Experience. Teoksessa Wallerstein, Immanuel. (Ed.), The Modern World-system in the Long Durée. Routledge. 157-198.

Schmidt-Thomé, Kaisa \& Hilkka Vihinen 2006. Rural Areas - Urban-rural Interaction and Beyond. Teoksessa Eskelinen, Heikki \& Timo Hirvonen (eds.). Positioning Finland in a European Space. Edita, Helsinki. 41-53. 